\title{
Synthesis and application of novel bicyclic guanidines: $N$-alkylation of 1,5,7-triazabicyclo[4.4.0]dec-5-ene
}

\author{
Thorsten Genski, ${ }^{a}$ Gregor Macdonald, ${ }^{\text {a }}$ Xudong Wei, ${ }^{\text {a Norman Lewis }}{ }^{\text {, }}$, and Richard J. K. \\ Taylor $^{\mathbf{a}^{*}}$ \\ ${ }^{a}$ Department of Chemistry, University of York,Heslington, York YO10 5DD, UK \\ ${ }^{\mathrm{b}}$ SmithKline Beecham Pharmaceuticals, Leigh,Tonbridge, Kent TN11 9AN, UK \\ E-mail: rjkt1@york.ac.uk
}

\section{Dedicated to Gurnos Jones on the occasion of his $70^{\text {th }}$ birthday}

(received 14 Feb 00; accepted 25 Apr 00; published on the web 03 May 00)

\begin{abstract}
The regioselective ring-opening reaction of optically pure epoxides by 1,5,7triazabicyclo[4.4.0]dec-5-ene was employed to prepare enantiomerically pure guanidine bases. A further example was prepared by deprotonation of 7-methyl-1,5,7-triazabicyclo[4.4.0]dec-5-ene followed by trapping with ()-camphor. Four of these bases were evaluated in the asymmetric epoxidation of 3-tert-butoxycarbonylamino-4,4-dimethoxycyclohexa-2,5-dien-1-one (4) and trans-chalcone using t-butyl hydroperoxide. Reasonable yields of the epoxide were obtained from the chalcone reaction but the ee's were low; with the quinone monoacetal 4 ee's in the range $29-35 \%$ were obtained.
\end{abstract}

Keywords: Bicyclic guanidines, epoxides, enantio selective epoxidation triazabicyclodec-5-ene alkylation

\section{Introduction}

Enantiomerically pure guanidines have attracted considerable recent attention as chiral basic catalysts for asymmetric processes ${ }^{1}$ and as chiral molecular hosts. ${ }^{2}$ Thus, for example, 1 has been used as a catalyst for the asymmetric Strecker synthesis of $\alpha$-amino acids, ${ }^{1 \text { a }}$ and the protonated version of 2 has been employed as an artificial receptor for oxyanionic guest species. ${ }^{2}$ In this paper we describe the preparation of a range of enantiomerically pure guanidines $3 \mathrm{c}-\mathrm{h} .^{3}$

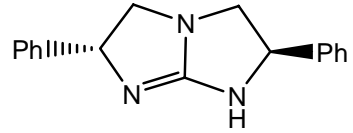

1

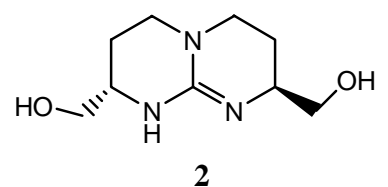

2<smiles>[R]N1CCCN2CCCN=C12</smiles>
3a, $\mathrm{R}=\mathrm{H}$
3b, $\mathrm{R}=\mathrm{Me}$
3c, $\mathrm{R}=$ chiral substituent 
Our interest in novel guanidines arose during a natural product synthesis programme in which we investigated the epoxidation reactions of substituted cyclohexenones and quinones. ${ }^{4}$ In the case of enone 4 (Scheme 1) and related amidoquinones, ${ }^{4 a}$ we found that the optimum published epoxidation procedure involved the use of $t$-butyl hydroperoxide (TBHP) and 1,8diazabicyclo[5.4.0]undec-5-ene (DBU). ${ }^{5}$ In seeking to extend this procedure we decided to investigate the use of 1,5,7-triazabicyclo[4.4.0]dec-5-ene (TBD) $3 \mathrm{a}$ and its derivatives in combination with TBHP. TBD (3a) and its $N$-methyl derivative $3 b$ have both been used to catalyse Michael additions, ${ }^{6}$ as have enantiopure $C$-substituted analogues. ${ }^{1 \mathrm{c}} \mathrm{We}$ were attracted to TBD and its derivatives for several reasons. Compounds $3 \mathrm{a}$ and $3 \mathrm{~b}$ are commercially available, and conversion of $3 \mathrm{a}$ into other $\mathrm{N}$-substituted derivatives is possible. ${ }^{7}$ We felt that this gave the potential for tuning the reactivity of the base and for preparing enantiomerically pure analogues. In addition, the preparation of solid-supported variants can be accomplished. ${ }^{8}$ Herein we report the conversion of $3 a$ and $3 b$ into chiral TBD derivatives $3 c-h$ and their use for the asymmetric epoxidation of amidoquinone $4 .^{3}$
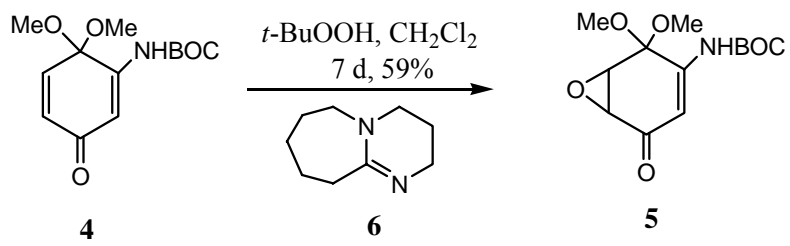

Scheme 1

\section{Results and Discussion}

\section{(a) Preparation of enantiomerically pure guanidines}

Acyclic and monocyclic guanidines are relatively straightforward to prepare, but synthetic routes to bicyclic guanidines, particularly enantiopure analogues with stereogenic centres on the ring adjacent to the secondary nitrogen atoms (e.g. 2), are rather lengthy. ${ }^{1,2}$ As discussed above, our aim was to start with the preformed bicyclic system $3 \mathrm{a}$ and to introduce an exocyclic stereogenic centre by $\mathrm{N}$-alkylation of $3 \mathrm{a}$ with an enantiomerically pure electrophile. The use of chiral epoxides was investigated first (Scheme 2) as the resulting alcohol functionality would allow further derivatisation of the functionalised guanidine, if necessary.

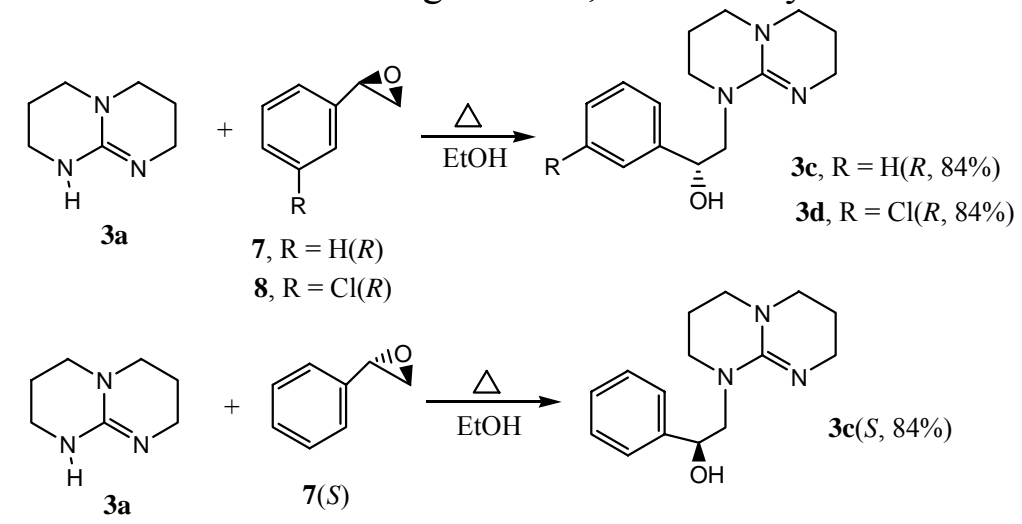

Scheme 2 
Reaction of TBD (3a) with (R)-styrene oxide (7) was accomplished in hot ethanol. Low conversion $(<5 \%)$ was observed in polar aprotic solvents (e.g. THF) and higher temperatures led to the formation of inseparable, unidentified by-products. Adduct $3 \mathrm{c}$ was obtained in $84 \%$ yield as a single regioisomer after purification $\left\{[\alpha]_{\mathrm{D}}-28.5\left(\right.\right.$ c 1.02, $\left.\left.\mathrm{CHCl}_{3}\right)\right\}$. The corresponding reaction using $(S)$-styrene oxide 7 was also performed giving the enantiomeric guanidine $S$-3c (Scheme 1); chiral shift ${ }^{1} \mathrm{H}$ NMR experiments on $R$ - and $S$-3c using 0.3 equivalents of $(R)-2,2,2-$ trifluoro-1-(9-anthryl)ethanol confirmed an enantiomeric excess of $>95 \%$ in each case.

Literature precedent ${ }^{9}$ suggests that styrene oxide opening by amines is likely to occur at the least hindered terminal site; regioselective guanidine-epoxide coupling reactions have been previously reported. ${ }^{10}$ Attempts to modify the styrene oxide ring-opening conditions to favour nucleophilic attack at the benzylic position (e.g. using tin chemistry, ${ }^{11}$ zeolites, ${ }^{12} \mathrm{Yb}(\mathrm{OTf}) 3,{ }^{13}$ lithium perchlorate $^{14}$ or iodine ${ }^{14}$ were unsuccessful. We also attempted to methylate $3 \mathrm{c}$ in order to evaluate the impact of the free hydroxyl group in epoxidation reactions. Unfortunately, methylation under a number of standard conditions (e.g. $\mathrm{NaH}, \mathrm{MeI}, \mathrm{DMF}$ ) afforded an inseparable mixture of $N$ - and $O$-methylated compounds.

The meta-chloro substituted analogue $3 \mathrm{~d}\left\{84 \% ;\left\{[\alpha]_{\mathrm{D}}-51.3\left(\right.\right.\right.$ c $\left.\left.1.02, \mathrm{CHCl}_{3}\right)\right\}$ was also prepared from TBD and the corresponding substituted styrene oxide 8. Chiral shift ${ }^{1} \mathrm{H}$ NMR spectroscopy using 0.3 equivalents of (R)-2,2,2-trifluoro-1-(9-anthryl)ethanol indicated an enantiomeric excess of $>95 \%$.

The success of the above strategy encouraged us to utilise more functionalised chiral epoxides in reactions with TBD (Scheme 3). Reaction of TBD 3a with glycidol 9 in ethanol gave a complex product mixture and although the expected reaction appeared to proceed in THF as solvent, purification of adduct 3e proved impossible. We therefore turned our attention to the use of (2S, 3R)-phenylglycidol 10 (Scheme 3). Following a published protocol, ${ }^{15}$ treatment of TBD with epoxide 10 and two equivalents of titanium iso-propoxide in dichloromethane gave the expected product $3 \mathrm{f}$ in $81 \%$ yield $\left\{[\alpha]_{\mathrm{D}}-12.3\left(\mathrm{c} 1.02, \mathrm{CHCl}_{3}\right)\right\}$.

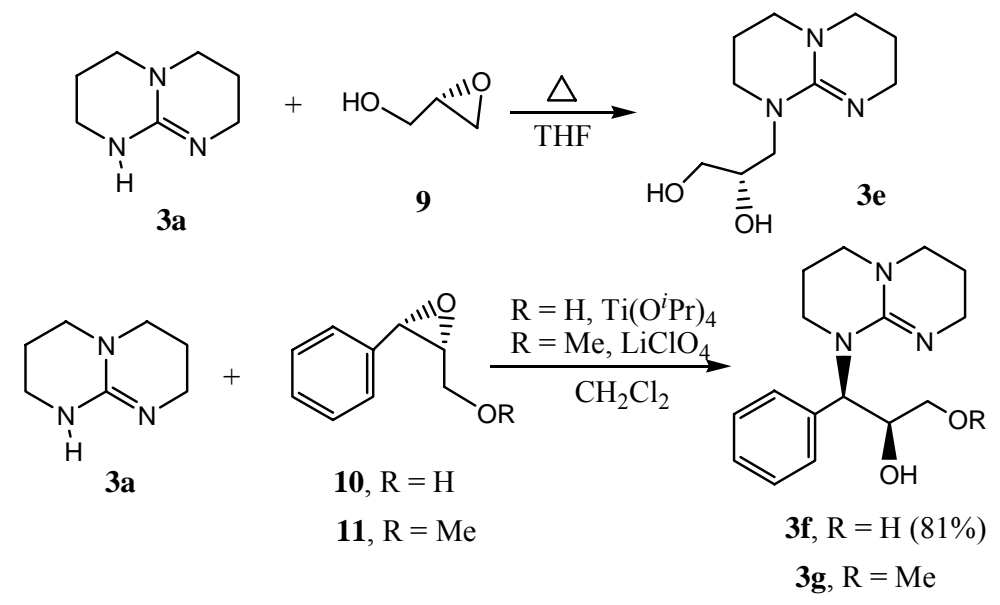

\section{Scheme 3}

We also required the corresponding methyl ether $3 \mathrm{~g}$ to assess the importance of the primary hydroxyl group of $3 \mathrm{f}$ in epoxidation processes. In view of the problems with methylation 
outlined above, we attempted to prepare $3 \mathrm{~g}$ from the reaction between TBD and epoxide 11 promoted by lithium perchlorate. ${ }^{15}$ Unfortunately, a large excess of TBD was required to drive the reaction to completion, and then purification of the product mixture proved impossible. Other Lewis-acids [e.g. $\left.\mathrm{Zn}(\mathrm{OTf})_{2}, \mathrm{Ti}(\mathrm{OiPr})_{4}\right]$ resulted in formation of inseparable by-products.

Finally, we devised a procedure for preparing enantiomerically pure guanidines 3 from ketones (Scheme 4). Deprotonation of the methylated TBD derivative $3 \mathrm{~b}$ was achieved using secbutyllithium 16 and treatment of the resulting lithiated species with $\mathrm{CeCl} 3$ and ()-camphor produced adduct $3 \mathrm{~h}$ as a single diastereoisomer in $45 \%$ yield (the stereochemistry being assigned by literature ${ }^{17}$ precedent). Reaction without cerium trichloride gave poor yields $(8-15 \%)$ of the desired product.
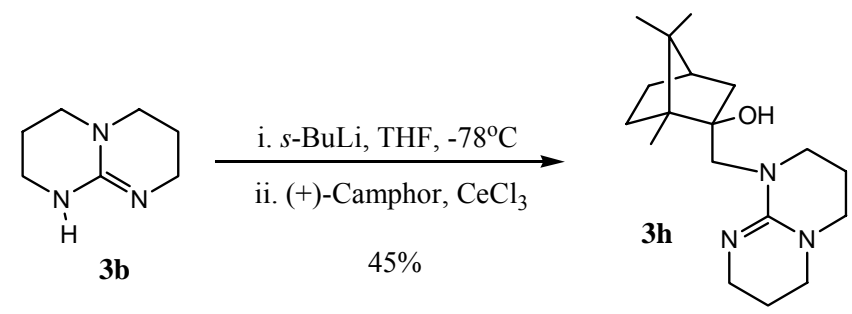

\section{Scheme 4}

\section{(b) Enantioselective epoxidation reactions}

A number of promising procedures are available for the asymmetric epoxidation of electron deficient alkenes ${ }^{18}$ but none give high enantiomeric excesses (ee) with cyclic enones. We have previously utilised Wynbergs pioneering cinchona-based phase transfer epoxidation procedure with dienone 4 to produce (-)-5 in $89 \%$ ee: ${ }^{4 c}$ this enantiomerically enriched material was subsequently employed in chiral syntheses of Manumycin A and related natural products. ${ }^{4 b, c} \mathrm{We}$ therefore investigated the use of chiral bases $3 c, d$ and $f$ in the TBHP epoxidation of dienone 4 : the results are collected in Table 1.

Table 1. Epoxidation of 4 using TBHP and chiral bases 3 in PhMe

\begin{tabular}{ccccc}
\hline Entry & Base & Yield 5 $(\%)$ & {$[\alpha]^{20} \mathrm{D}$} & ee $5(\%) ;()-$ or $(-)$ \\
$\mathrm{i}^{\mathrm{a}}$ & $R-3 \mathrm{c}$ & 31 & -65 & $35(-)$ \\
$\mathrm{ii}$ & $S-3 \mathrm{c}$ & 32 & 60 & 32() \\
iii & $3 \mathrm{~d}$ & 23 & -55 & $29(-)$ \\
iv & $3 \mathrm{f}$ & 7 & 15 & 8() \\
\hline
\end{tabular}

${ }^{\mathrm{a}}$ In a biphasic system $\left(\mathrm{H}_{2} \mathrm{O} / \mathrm{PhMe}\right)$ the yield and ee decreased (21\% and $18 \%$ respectively).

As can be seen from Table 1, the styrene oxide derived base $3 \mathrm{c}$ gave an encouraging ee (32$35 \%$ ), $R-3 \mathrm{c}$ producing a predominance of ()-5 and $S-3 \mathrm{c}$ producing (-)-5 (the $2 S, 3 R$-enantiomer also produced by the chiral phase transfer procedure).$^{4 \mathrm{c}}$ The chlorinated analogue $3 \mathrm{~d}$ gave similar results but we were disappointed to find that base $3 \mathrm{f}$, which has a stereogenic centre adjacent to the guanidine nitrogen, gives 5 in low ee and low yield. Preliminary studies were also carried out on the asymmetric epoxidation of trans-chalcone. In these reactions the yields were much higher but disappointing ee's were observed (e.g. with $3 \mathrm{~d}$, 71\% yield, 9\% ee). 
These results illustrate the potential of enantiomerically pure guanidine bases for the asymmetric epoxidation of electron deficient alkenes. However, further studies are required to elucidate the key structural features of these bases and so to enable the rational design of improved systems.

\section{Experimental Section}

General Procedures. Tetrahydrofuran was distilled from sodium-benzophenone ketyl immediately before use. Petroleum ether refers to the fraction with bp $40-60{ }^{\circ} \mathrm{C}$ and was redistilled before use. Toluene was dried over molecular sieves ( $4 \AA$ ) prior to use. Water is distilled water and brine is a stock solution of saturated aqueous sodium chloride solution. Column chromatography was performed on ICN silica gel (32-63) using the eluent specified under medium pressure. All reagents were purchased from commercial suppliers and were used without further purification. Melting points are uncorrected. IR spectra were recorded in the FT mode. Optical rotation values were measured on a JASCO DIP-370 digital polarimeter fitted with a sodium lamp running 10 measurement cycles allowing 30 seconds integration time. The compounds were analysed as a solution in chloroform (AR spectroscopic grade) at $20{ }^{\circ} \mathrm{C}$. Compounds $4^{4 \mathrm{a}}$ and $11^{15}$ were prepared following literature procedures.

(1R)-2-(Triazabicyclo[4.4.0]dec-5-en-7-yl)-1-phenylethanol ( $R$-3c). TBD (1.00 g, $7.18 \mathrm{mmol})$ and $(R)$-styrene oxide $(0.95 \mathrm{~g}, 7.91 \mathrm{mmol})$ were heated in ethanol $\left(25 \mathrm{~cm}^{3}\right)$ at gentle reflux for 90 min. Removal of the solvent afforded a pale yellow oil which was taken up in 4M hydrochloric acid $(18 \mathrm{~mL})$ and extracted with diethyl ether $(2 \times 5 \mathrm{~mL})$. The aqueous layer was brought to $\mathrm{pH}=14$ with a minimum amount of saturated aqueous sodium hydroxide solution. Extraction with dichloromethane $(6 \times 20 \mathrm{~mL})$ followed. The combined organic layers were dried $\left(\mathrm{MgSO}_{4}\right)$, filtered and concentrated in vacuo to give the title compound $3 \mathrm{c}(1.56 \mathrm{~g}, 84 \%)$ as a white sticky solid, IR (NaCl, film) $v_{\max } / \mathrm{cm}^{-1} 3306,1603,1124 ;{ }^{1} \mathrm{H}$ NMR $\left(270 \mathrm{MHz}, \mathrm{CDCl}_{3}\right) \delta$ $7.42(2 \mathrm{H}, \mathrm{t}, J$ 7.0, Ph), $7.33(2 \mathrm{H}, \mathrm{d}, J$ 7.0, Ph), 7.29-7.23 (1H, m, Ph), 4.99 (1H, dd, J 6.0, 4.5, $\left.\mathrm{CH}(\mathrm{OH}) \mathrm{CH}_{\mathrm{A}} \mathrm{H}_{\mathrm{B}} \mathrm{N}\right), 3.89\left(1 \mathrm{H}, \mathrm{dd}, J 14.5,6.0, \mathrm{CH}(\mathrm{OH}) \mathrm{CH}_{\mathrm{A}} \mathrm{H}_{\mathrm{B}} \mathrm{N}\right), 3.42(1 \mathrm{H}, \mathrm{dd}, J$ 14.5, 4.5, $\left.\mathrm{CH}(\mathrm{OH}) \mathrm{CH}_{\mathrm{A}} \mathrm{H}_{\mathrm{B}} \mathrm{N}\right), 3.46-3.36\left(2 \mathrm{H}, \mathrm{m}, \mathrm{CH}_{2} \mathrm{~N}\right), 3.23-3.19\left(2 \mathrm{H}, \mathrm{m}, \mathrm{CH}_{2} \mathrm{~N}\right), 3.10(2 \mathrm{H}, \mathrm{t}, J$ 6.0, $\left.\mathrm{CH}_{2} \mathrm{~N}\right), 2.96\left(1 \mathrm{H}\right.$, quint, $\left.J 6.0, \mathrm{CH}_{2} \mathrm{~N}\right), 2.77\left(1 \mathrm{H}\right.$, quint, $\left.J 6.0, \mathrm{CH}_{2} \mathrm{~N}\right), 1.90(2 \mathrm{H}$, quint, $J$ 6.0, $\left.\mathrm{NCH}_{2} \mathrm{CH} 2 \mathrm{CH}_{2} \mathrm{~N}\right), 1.76\left(2 \mathrm{H}\right.$, quint, $J$ 6.0, $\left.\mathrm{NCH}_{2} \mathrm{CH}_{2} \mathrm{CH}_{2} \mathrm{~N}\right) ;{ }^{13} \mathrm{C} \mathrm{NMR}\left(67.5 \mathrm{MHz}, \mathrm{CDCl}_{3}\right) \delta$ $152.2\left(\mathrm{C}, \mathrm{CN}_{3}\right), 143.4(\mathrm{C}, \mathrm{C}-1 \mathrm{Ph}), 128.0(2 \mathrm{CH}), 127.0(\mathrm{CH}), 126.2(2 \mathrm{CH}), 72.4(\mathrm{CH}$, $\left.\mathrm{CH}(\mathrm{OH}) \mathrm{CH}_{2} \mathrm{~N}\right), 59.2\left(\mathrm{CH}_{2}, \mathrm{CH}(\mathrm{OH}) \mathrm{CH}_{2} \mathrm{~N}\right), 48.1\left(\mathrm{CH}_{2}, \mathrm{TBD}\right), 47.9\left(\mathrm{CH}_{2}, \mathrm{TBD}\right), 47.5\left(\mathrm{CH}_{2}\right.$, TBD), 40.7 ( $\left.\mathrm{CH}_{2}, \mathrm{TBD}\right), 21.8$ (2 $\mathrm{CH}_{2}$, TBD); MS (EI) m/z 259 (M, 10\%), 242 (17), 152 (68), 139 (100); HRMS (EI) $\mathrm{m} / \mathrm{z} 259.1685\left(\mathrm{C}_{15} \mathrm{H}_{21} \mathrm{~N}_{3} \mathrm{O}\right.$ requires 259.1683, 0.6 ppm error); $[\alpha]^{20}=-28.5(\mathrm{c}$ $\left.1.02, \mathrm{CHCl}_{3}\right)$.

(1S)-2-(Triazabicyclo[4.4.0]dec-5-en-7-yl)-1-phenylethanol (S-3c). Prepared in 65\% yield as a white sticky solid following the procedure for $R-3 \mathrm{c}$ starting from $(S)$-styrene oxide, $[\alpha]^{20}=.2$ (c 0.94, $\mathrm{CHCl}_{3}$ ).

(1R)-2-(1,5,7-Triazabicyclo[4.4.0]dec-5-en-7-yl)-1-(3-chlorophenyl)ethanol (3d). Following the procedure above and using TBD (327 mg, $2.35 \mathrm{mmol})$ and (R)-3-chlorostyrene oxide (8) 
(397 $\mathrm{mg}, 2.57 \mathrm{mmol}$ ), the title compound $3 \mathrm{~d}$ as a white sticky solid (578 $\mathrm{mg}, 84 \%$ ) was obtained, IR (NaCl, film) $v_{\max } / \mathrm{cm}^{-1} 3369,1599,1321,754 ;{ }^{1} \mathrm{H}$ NMR $\left(270 \mathrm{MHz}, \mathrm{CDCl}_{3}\right) \delta 7.42(1 \mathrm{H}, \mathrm{m}$, $\mathrm{Ph}), 7.33-7.18(3 \mathrm{H}, \mathrm{m}, \mathrm{Ph}), 4.97\left(1 \mathrm{H}, \mathrm{dd}, J\right.$ 6.0, 4.0, $\left.\mathrm{CH}(\mathrm{OH}) \mathrm{CH}_{\mathrm{A}} \mathrm{H}_{\mathrm{B}} \mathrm{N}\right), 3.79(1 \mathrm{H}, \mathrm{dd}, J$ 15.0, 6.0, $\left.\mathrm{CH}(\mathrm{OH}) \mathrm{CH}_{A} \mathrm{H}_{\mathrm{B}} \mathrm{N}\right), 3.46\left(1 \mathrm{H}, \mathrm{dd}, J\right.$ 15.0, 4.0, $\left.\mathrm{CH}(\mathrm{OH}) \mathrm{CH}_{\mathrm{A}} \mathrm{H}_{\mathrm{B}} \mathrm{N}\right), 3.45-3.40\left(2 \mathrm{H}, \mathrm{m}, \mathrm{CH}_{2} \mathrm{~N}\right)$, 3.24-3.19 $\left(2 \mathrm{H}, \mathrm{m}, \mathrm{CH}_{2} \mathrm{~N}\right), 3.14-3.10\left(2 \mathrm{H}, \mathrm{m}, \mathrm{CH}_{2} \mathrm{~N}\right), 3.04-2.95\left(1 \mathrm{H}, \mathrm{m}, \mathrm{CH}_{2} \mathrm{~N}\right), 2.83-2.75(1 \mathrm{H}$, $\left.\mathrm{m}, \mathrm{CH}_{2} \mathrm{~N}\right), 1.95-1.75\left(4 \mathrm{H}, \mathrm{m}, 2 \times \mathrm{NCH}_{2} \mathrm{CH} 2 \mathrm{CH}_{2} \mathrm{~N}\right) ;{ }^{13} \mathrm{C} \mathrm{NMR}\left(67.5 \mathrm{MHz}, \mathrm{CDCl}_{3}\right) \delta 152.3(\mathrm{C}$, $\left.\mathrm{CN}_{3}\right), 145.9(\mathrm{C}, \mathrm{C}-1 \mathrm{Ph}), 133.8(\mathrm{C}, \mathrm{C}-3 \mathrm{Ph}), 129.3(\mathrm{CH}), 127.0(\mathrm{CH}), 126.3(\mathrm{CH}), 124.4(\mathrm{CH})$, $72.0\left(\mathrm{CH}, \mathrm{CH}(\mathrm{OH}) \mathrm{CH}_{2} \mathrm{~N}\right), 59.0\left(\mathrm{CH}_{2}>, \mathrm{CH}(\mathrm{OH}) \mathrm{CH}_{2} \mathrm{~N}\right), 48.1\left(\mathrm{CH}_{2}, \mathrm{TBD}\right), 48.0\left(\mathrm{CH}_{2}, \mathrm{TBD}\right)$, $47.5\left(\mathrm{CH}_{2}, \mathrm{TBD}\right), 40.8$ ( $\left.\mathrm{CH}_{2}, \mathrm{TBD}\right), 21.8\left(2 \mathrm{CH}_{2}, \mathrm{TBD}\right)$; MS (EI) m/z 293 (M, 4\%), 276 (11), 152 (72), 139 (100); HRMS (CI) m/z 294.1369 (M) $\left(\mathrm{C}_{15} \mathrm{H}_{21}{ }^{35} \mathrm{ClN}_{3} \mathrm{O}\right.$ requires 294.1373, $1.1 \mathrm{ppm}$ error); $[\alpha]^{20}{ }_{\mathrm{D}}=-51.3\left(\mathrm{c} 1.02, \mathrm{CHCl}_{3}\right)$.

(2S,3R)-3-(1,5,7-Triazabicyclo[4.4.0]dec-5-en-7-yl)-3-phenyl-1,2-propandiol (3f). To a solution of $(2 S, 3 R)$-phenylglycidol $(10)(765 \mathrm{mg}, 5.09 \mathrm{mmol})$ in dichloromethane $(35 \mathrm{~mL}) \mathrm{TBD}$ (506 $\mathrm{mg}, 3.64 \mathrm{mmol})$ and titanium(IV) iso-propoxide $(2.17 \mathrm{~g}, 7.63 \mathrm{mmol})$ were added at room temperature under nitrogen atmosphere. After stirring at $35{ }^{\circ} \mathrm{C}$ for 3 days the reaction was quenched with a $10 \%$ solution of sodium hydroxide in brine $(35 \mathrm{~mL})$. Vigorous stirring was continued for another 2 days. The mixture was filtered through celite and the residue was washed with dichloromethane several times. The aqueous layer was separated and extracted with dichloromethane $(3 \times 10 \mathrm{~mL})$. The combined organic layers were dried $\left(\mathrm{MgSO}_{4}\right)$, filtered and concentrated in vacuo. The pale yellow oil obtained was dissolved in $1.4 \mathrm{M}$ hydrochloric acid $(22 \mathrm{~mL})$ and extracted with diethyl ether $(2 \times 7 \mathrm{~mL})$. The aqueous solution was brought to $\mathrm{pH}=$ 14 with a minimum amount of saturated aqueous sodium hydroxide solution. Extraction with dichloromethane $(6 \times 20 \mathrm{~mL})$ followed. The combined organic layers were dried $\left(\mathrm{MgSO}_{4}\right)$, filtered and concentrated in vacuo to give the title compound $3 \mathrm{f}(855 \mathrm{mg}, 81 \%)$ as a white sticky solid, IR ( NaCl, film) $v_{\max } / \mathrm{cm}^{-1} 3318,1579,1441,1309,1103,1047,752 ;{ }^{1} \mathrm{H} \mathrm{NMR}(270 \mathrm{MHz}$, $\left.\mathrm{CDCl}_{3}\right) \quad \delta 7.43(2 \mathrm{H}$, br d, J 7.0, $\mathrm{Ph}), 7.36-7.26(3 \mathrm{H}, \mathrm{m}, \mathrm{Ph}), 5.44(1 \mathrm{H}, \mathrm{d}, J$ 11.0, $\mathrm{NCH}(\mathrm{Ph}) \mathrm{CH}(\mathrm{OH}), 4.16\left(1 \mathrm{H}, \mathrm{dt}, J 11.0,2.0, \mathrm{CH}(\mathrm{OH}) \mathrm{CH}_{\mathrm{A}} \mathrm{H}_{\mathrm{B}} \mathrm{OH}\right), 3.77(1 \mathrm{H}, \mathrm{dd}, J$ 12.0, 2.0, $\left.\mathrm{CH}(\mathrm{OH}) \mathrm{CH}_{A} \mathrm{H}_{\mathrm{B}} \mathrm{OH}\right), 3.68\left(1 \mathrm{H}, \mathrm{dd}, J 12.0,2.0, \mathrm{CH}(\mathrm{OH}) \mathrm{CH}_{\mathrm{A}} \mathrm{H}_{\mathrm{B}} \mathrm{OH}\right), 3.52-3.37\left(1 \mathrm{H}, \mathrm{m}, \mathrm{CH}_{2} \mathrm{~N}\right)$, 3.30-3.01 (5H, m, $\left.\mathrm{CH}_{2} \mathrm{~N}\right), 2.93-2.76\left(2 \mathrm{H}, \mathrm{m}, \mathrm{CH}_{2} \mathrm{~N}\right), 1.91-1.81\left(2 \mathrm{H}, \mathrm{m}, \mathrm{NCH}_{2} \mathrm{CH}_{2} \mathrm{CH}_{2} \mathrm{~N}\right), 1.76-$ $1.63\left(1 \mathrm{H}, \mathrm{m}, \mathrm{NCH}_{2} \mathrm{CH}_{2} \mathrm{CH}_{2} \mathrm{~N}\right), 1.56-1.44\left(1 \mathrm{H}, \mathrm{m}, \mathrm{NCH}_{2} \mathrm{CH}_{2} \mathrm{CH}_{2} \mathrm{~N}\right) ;{ }^{13} \mathrm{C} \mathrm{NMR}(67.5 \mathrm{MHz}$, $\left.\mathrm{CDCl}_{3}\right) \delta 152.1\left(\mathrm{C}, \mathrm{CN}_{3}\right), 137.4(\mathrm{C}, \mathrm{C}-1 \mathrm{Ph}), 129.3(2 \mathrm{CH}), 128.3(2 \mathrm{CH}), 127.5(\mathrm{CH}), 69.7(\mathrm{CH}$, $\mathrm{CH}(\mathrm{OH}) \mathrm{CH}<\mathrm{sub} 2 \mathrm{OH}), 62.7\left(\mathrm{CH}_{2}, \mathrm{CH}(\mathrm{OH}) \mathrm{CH}_{2} \mathrm{OH}\right), 58.9(\mathrm{CH}, \mathrm{NCH}(\mathrm{Ph}) \mathrm{CH}(\mathrm{OH})), 48.4\left(\mathrm{CH}_{2}\right.$, TBD), 47.9 ( $\left.\mathrm{CH}_{2}, \mathrm{TBD}\right), 41.3\left(\mathrm{CH}_{2}, \mathrm{TBD}\right), 40.0\left(\mathrm{CH}_{2}, \mathrm{TBD}\right), 22.2\left(2 \mathrm{CH}_{2}, \mathrm{TBD}\right)$; $\mathrm{MS}(\mathrm{EI}) \mathrm{m} / \mathrm{z}$ 289 (M, 18\%), 272 (12), 258 (100), 139 (98); HRMS (CI) m/z $290.1867\left(\mathrm{C}_{16} \mathrm{H}_{24} \mathrm{~N}_{3} \mathrm{O}_{2}\right.$ requires 290.18685, 0.6 ppm error); $[\alpha]^{20}=-12.3\left(c 1.02, \mathrm{CHCl}_{3}\right)$.

(1R,2R,4R)-1,7,7-Trimethyl-2-(1,5,7-triazabicyclo[4.4.0]dec-5-en-7-ylmethyl)bicyclo[2.2.1]heptan-2-ol (3h). To a stirred solution of 7-methyl-1,5,7-triazabicyclo[4.4.0]dec-5-ene (3b) $(153 \mathrm{mg}, 1.0 \mathrm{mmol})$ in tetrahydrofuran $(10 \mathrm{~mL})$ under nitrogen atmosphere and at $-78{ }^{\circ} \mathrm{C}$ was added sec-butyllithium $(0.92 \mathrm{~mL}, 1.3 \mathrm{M}$ solution in cyclohexane, $1.2 \mathrm{mmol})$. The reaction mixture was stirred at $-78{ }^{\circ} \mathrm{C}$ for $1 \mathrm{~h}$ and then transferred by cannular to a solution of ()-camphor $(152 \mathrm{mg}, 1.0 \mathrm{mmol})$ and cerium chloride $(250 \mathrm{mg}, 1.0 \mathrm{mmol})$ in tetrahydrofuran $(10 \mathrm{~mL})$ at room temperature. After stirring for $4 \mathrm{~h}$ the reaction was quenched with a small amount of water $(0.5 \mathrm{~mL})$. The tetrahydrofuran was evaporated, $1 \mathrm{M}$ hydrochloric acid $(30 \mathrm{~mL})$ was added, and 
the solution was washed with diethyl ether $(3 \times 30 \mathrm{~mL})$. The aqueous layer was cooled to $0{ }^{\circ} \mathrm{C}$ with ice and solid sodium hydroxide was added slowly to adjust the $\mathrm{pH} \geq 12$. The alkaline solution was extracted with diethyl ether $(6 \times 30 \mathrm{~mL})$. After drying $\left(\mathrm{Na}_{2} \mathrm{SO}_{4}\right)$ and removal of the solvent, the title product $3 \mathrm{~h}(137 \mathrm{mg}, 45 \%)$ was obtained as a white solid, mp $139-141{ }^{\circ} \mathrm{C}$; IR (NaCl, nujol) $v_{\max } / \mathrm{cm}^{-1} 2952,2924,1588,1515,1452,1309,1219 ;{ }^{1} \mathrm{H} \mathrm{NMR}\left(270 \mathrm{MHz}, \mathrm{CDCl}_{3}\right)$ $\delta 3.53\left(1 \mathrm{H}, \mathrm{d}, J 14.3, \mathrm{C}(\mathrm{OH}) \mathrm{CH}_{\mathrm{A}} \mathrm{H}_{B} \mathrm{~N}\right), 3.39-3.15\left(5 \mathrm{H}, \mathrm{m}, 2 \times \mathrm{CH}_{2}\right.$ TBD and $\left.\mathrm{C}(\mathrm{OH}) \mathrm{CH}_{A} \mathrm{H}_{\mathrm{B}} \mathrm{N}\right)$, 3.12-3.05 (4H, m, $2 \times \mathrm{CH}_{2}$ TBD), 2.03-1.92 (3H, m, $\mathrm{CH}_{2} \mathrm{TBD}$ and $\mathrm{H}-3_{\text {exo }}$ ), 1.82-1.72 (2H, m, $\mathrm{CH}_{2}$ TBD), 1.71-1.62 (2H, m, H-4, H-5 exo), 1.50-1.25 (3H, m, H-6, H-3 endo), 1.43 (1H, s, OH), $1.11\left(3 \mathrm{H}, \mathrm{s}, \mathrm{CH}_{3}-8\right), 1.00-0.82(1 \mathrm{H}, \mathrm{m}, \mathrm{H}-5$ endo $), 0.92\left(3 \mathrm{H}, \mathrm{s}, \mathrm{CH}_{3}-9\right), 0.81\left(3 \mathrm{H}, \mathrm{s}, \mathrm{CH}_{3}-10\right) ;{ }^{13} \mathrm{C}$ NMR (67.5 MHz, $\left.\mathrm{CDCl}_{3}\right) \delta 153.9\left(\mathrm{C}, \mathrm{CN}_{3}\right), 81.2(\mathrm{C}, \mathrm{C}-2), 60.1\left(\mathrm{CH}_{2}, \mathrm{C}-11\right), 51.9(\mathrm{C}, \mathrm{C}-1), 49.6$ ( $\left.\mathrm{CH}_{2}, \mathrm{TBD}\right), 49.3$ (C, C-7), 48.4 ( $\left.\mathrm{CH}_{2}, \mathrm{TBD}\right), 48.3\left(\mathrm{CH}_{2}, \mathrm{TBD}\right), 46.2\left(\mathrm{CH}_{2}, \mathrm{C}-3\right), 44.9(\mathrm{CH}, \mathrm{C}-$ 4), $42.4\left(\mathrm{CH}_{2}, \mathrm{TBD}\right), 30.2\left(\mathrm{CH}_{2}, \mathrm{C}-6\right), 27.2\left(\mathrm{CH}_{2}, \mathrm{C}-5\right), 23.1\left(\mathrm{CH}_{2}, \mathrm{TBD}\right), 22.7\left(\mathrm{CH}_{2}, \mathrm{TBD}\right)$, $21.4\left(\mathrm{CH}_{3}, \mathrm{C}-8\right), 20.6\left(\mathrm{CH}_{3}, \mathrm{C}-9\right), 11.2\left(\mathrm{CH}_{3}, \mathrm{C}-10\right)$; MS (EI) m/z 305 (M, 20\%), 290 (60), 153 (100), 139 (60), 124 (40), 84 (60); HRMS (EI) m/z 305.2462 $\left(\mathrm{C}_{18} \mathrm{H}_{31} \mathrm{~N}_{3} \mathrm{O}\right.$ requires 305.2467, 1.5 ppm error); $[\alpha]^{20}=.7$ (c $\left.0.3, \mathrm{CHCl}_{3}\right)$

Asymmetric epoxidation of 4. General procedure. Chiral guanidine 3 (1.2 equiv) was premixed with TBHP (5.5M anhydrous solution in decane) (2.0 equiv) in dried toluene ( $1 \mathrm{~mL} / 100 \mathrm{mg} 4)$ at room temperature for $3 \mathrm{~min}$. Then quinone acetal 4 (ca. $100 \mathrm{mg}$ ) was added and stirring was continued for 8 days. The reaction mixture was poured into water $(3 \mathrm{~mL})$ and extracted with ethyl acetate $(5 \times 10 \mathrm{~mL})$. The organic layer was dried $\left(\mathrm{MgSO}_{4}\right)$, filtered and concentrated in vacuo. After purification on silica using dichloromethane and ethyl acetate $(25: 1)$ as the eluent the epoxide acetal 5 was obtained as a white solid, with spectroscopic data consistent with those published. $^{4 \mathrm{c}}$

\section{Acknowledgements}

We are grateful to the EPSRC for the award of a Research Fellowship (X. W.) and a CASE Studentship (G. M.) and the DAAD and Elsevier Science Ltd for studentship support (T. G.).

\section{References and Notes}

1. (a) Corey, E. J.; Grogan, M. J. Org. Lett. 1999, 1, 157. (b) Alcázar, V.; Morán, J. R.; de Mendoza, J. Tetrahedron Lett. 1995, 36, 3941. (c) Chinchilla, R.; Nájera, C.; SánchezAgullá, P. Tetrahedron: Asymmetry 1994, 5, 1393.

2. (a) Kurzmeier, H.; Schmidtchen, F. P. J. Org. Chem. 1990, 55, 3749. (b) Schmidtchen, F. P.; Berger, M. Chem. Rev. 1997, 97, 1609.

3. Preliminary communication on part of this work: Genski, T.; Macdonald, G.; Wei, X.; Lewis, N.; Taylor, R. J. K. Synlett 1999, 795.

4. (a) Taylor, R. J. K.; Alcaraz, L.; Kapfer-Eyer, I.; Macdonald, G.; Wei, X.; Lewis, N. Synthesis 1998, 775. (b) Alcaraz, L.; Macdonald, G.; Ragot, J. P.; Lewis, N.; Taylor, R. J. K. 
J. Org. Chem. 1998, 63, 3526 and Tetrahedron 1999, 55, 3707. (c) Macdonald, G.; Alcaraz, L.; Lewis, N. J.; Taylor, R. J. K. Tetrahedron Lett. 1998, 39, 5433. (d) Dwyer, C. L.; Gill, C. D.; Ichihara, O.; Taylor, R. J. K. Synlett. 2000, 704.

5. (a) Schlessinger, R. H.; Bebernitz, G. R.; Lin, P.; Poss, A. J. J. Am. Chem. Soc. 1985, 107, 1777. (b) Yadav, V. K.; Kapoor, K. K. Tetrahedron 1995, 51, 8573.

6. Horváth, A. Tetrahedron Lett. 1996, 37, 4423.

7. (a) Alder, R. W.; Mowlam, R. W.; Vachon, D. J.; Weisman, G. R. J. Chem. Soc., Chem. Commun. 1992, 507. (b) Kosasayama, A.; Konno, T.; Higashi, K.; Ishikawa, F. Chem. Pharm. Bull. 1979, 27, 841.

8. Subba Rao, Y. V.; De Vos, D. E.; Jacobs, P. A. Angew. Chem., Int. Ed. 1997, 36, 2661.

9. (a) Anderson, S. R.; Ayers, J. T.; DeVries, K. M.; Ito, F.; Mendenhall, D.; Vanderplas, B. C. Tetrahedron: Asymmetty 1999, 10, 2655. (b) Gorzynski Smith, J. Synthesis 1984, 629.

10. Gravier-Pelletier, C.; Bourissou, D.; Le Merrer, Y.; Depezay, J.-C. Synlett 1996, 275.

11. (a) Casey, M.; Moody, C. J.; Rees, C. W. J. Chem. Soc., Chem. Commun. 1982, 714. (b) Fiorenza, M.; Ricci, A.; Taddei, M.; Tassi, D. Synthesis 1983, 640.

12. Onaka, M.; Kawai, M.; Izumi, Y. Chem. Lett. 1985, 779.

13. Chini, M.; Crotti, P.; Favero, L.; Macchia, F.; Pineschi, M. Tetrahedron Lett. 1994, 35, 433.

14. Iranpoor, N.; Tamami, B.; Niknam, K. Can. J. Chem. 1997, 75, 1913.

15. Vidal-Ferran, A.; Moyano, A.; Pericàs, M. A.; Riera, A. J. Org. Chem. 1997, 62, 4970.

16. (a) Choshi, T.; Yamada, S.; Sugino, E.; Kuwada, T.; Hibino, S. J. Org. Chem. 1995, 60, 5899. (b) Dimitrov, V.; Bratovanov, S.; Simova, S.; Kostova, K Tetrahedron Lett. 1994, 35, 6713 (c) Dimitrov, V.; Simova, S.; Kostova, K Tetrahedron 1996, 52, 1699.

17. For lead references see: (a) Enders, D.; Zhu, J.; Kramps, L. Liebigs Ann./Recueil 1997, 1101. (b) Watanabe, S.; Arai, T.; Sasai, H.; Bougauchi, M.; Shibasaki, M. J. Org. Chem. 1998, 63, 8090. (c) Elston, C. L.; Jackson, R. F. W.; MacDonald, S. J. F.; Murray, P. J. Angew. Chem., Int. Ed. 1997, 36, 410. (d) Corey, E. J.; Zhang, F.-Y. Org. Lett. 1999, 1, 1287. (e) Porter, M. J.; Roberts, S. M.; Skidmore, J. Bioorg. Med. Chem. 1999, 7, 2145. 